\title{
Chromosomal Localization of Human Glutamate Receptor Genes
}

\author{
James O. McNamara, ${ }^{1,2}$ James H. Eubanks, ${ }^{3,4}$ John D. McPherson, ${ }^{5}$ John J. Wasmuth, ${ }^{5}$ Glen A. Evans, ${ }^{3}$ and \\ Stephen F. Heinemann ${ }^{2}$ \\ 'Department of Veterans Affairs Medical Center, Departments of Medicine (Neurology), Neurobiology, and Pharmacology, \\ Duke University Medical Center, Durham, NC 27710, ${ }^{2}$ Molecular Neurobiology Laboratory and ${ }^{3}$ Molecular Genetics \\ Laboratory, The Salk Institute for Biological Studies, San Diego, California 92186-5800, 'Departments of Pharmacology \\ and Physiology, University of California, San Diego, California 92186-5800, and ${ }^{5}$ Department of Biological Chemistry, \\ California College of Medicine, University of California, Irvine, California 92717
}

\begin{abstract}
The chromosomal localization of human glutamate receptor genes (GluR1-4) has been established using PCR with DNA isolated from mapping panels of Chinese hamster-human hybrid cell lines and high-resolution fluorescent in situ suppression hybridization. This was accomplished with genomic clones containing putative human homologs of rat GluR1-4 isolated by high-stringency screening of a cosmid library with the rat cDNAs encoding GluR1-4. The locations of GluR1-4, respectively, are 5q32-33, 4q32-33, Xq25-26, and 11q22-23. Evidence implicating glutamatergic synapses in a diversity of physiologic and pathologic processes together with concordance of the chromosomal locales and results of linkage analyses establishes GluR3 and GluR4 as candidate genes for a number of nervous system disorders including the oculocerebral-renal syndrome of Lowe and a form of manic-depressive illness.
\end{abstract}

Synapses using excitatory amino acids such as glutamate are the principal excitatory synapses of the mammalian nervous system (Headley and Grillner, 1990). These synapses have been implicated in physiologic processes including the acquisition of associative learning (Morris, 1989), synapse formation (Constantine-Paton et al., 1990), and neuroendocrine function (Van Den Pol et al., 1990). These synapses have also been linked to a variety of pathologic processes. Glutamatergic synapses have been linked to both epileptogenesis and seizure expression in animal models (Dingledine et al., 1990). Several lines of evidence implicate glutamatergic synapses in neurodegenerative disorders, that is, nervous system diseases characterized by insidious and progressive degeneration of select populations of neurons. Sustained exposure to glutamate can kill neurons (Lucas and Newhouse, 1957; Olney, 1986). Glutamate receptor (GluR) antagonists protect against neuronal destruction following acute neurologic insults produced by ischemia or hypogly-

\footnotetext{
Received Oct. 4, 1991; revised Jan. 22, 1992; accepted Jan. 28, 1992.

We thank Jim Boulter, Irm Hermans-Borgmeyer, Robert Duvoisin, and Scott Rogers for advice and support throughout this study, Ann Saunders for helpful discussion of mouse genetic diseases, and Caryn Wagner-McPherson for assistance with in situ hybridization. This work was supported by grants from the Veterans Administration (J.O.M.), Fritz B. Burns Foundation, Weingart Foundation, and The Human Frontiers Science Program (S.F.H.). This work was also supported by NIH Grants NS17771 and NS24448 (J.O.M.), HG00320 (J.J.W.), HG00202 and GM33868 (G.A.E.), and NS1 1549 and NS28709 (S.F.H.).

Correspondence should be addressed to James O. McNamara, M.D., Box 3676 401 Bryan Research Building, Duke University Medical Center, Durham, NC 27710 .

Copyright (C) 1992 Society for Neuroscience $0270-6474 / 92 / 122555-08 \$ 05.00 / 0$
}

cemia (Simon et al., 1984; Wieloch, 1985). Epidemiologic studies have linked ingestion of neurotoxic excitatory amino acids to diseases with progressive neuronal loss (Spencer et al., 1987). The pivotal role of receptors in synaptic transmission implies that mutations of GluR genes could lead to synaptic malfunction and thereby cause a genetic disease of the nervous system manifest by defective development, epilepsy, neurodegeneration, or even psychiatric symptoms.

The molecular cloning by functional expression of a family of glutamate-gated ion channel receptors from a rat brain cDNA library (Hollmann et al., 1989; Boulter et al., 1990b; Keinanen et al., 1990) provided powerful tools to investigate these possibilities. Correlation of the chromosomal location of human GluR genes with loci of human diseases identified through linkage analyses is one approach to test the potential involvement of GluR genes in these disorders. The goal of this work was to clone the human GluR genes and to ascertain their chromosomal locations. We focused on a family of GluRs referred to as GluR1-4 (Hollmann et al., 1989; Boulter et al., 1990b) or GluRA-D (Keinanen et al., 1990), which exhibit a high degree of homology to one another and thereby differ from other GluRs and kainate-binding proteins (Bettler et al., 1991; Egebjerg et al., 1991; Werner et al., 1991). These cDNAs encode a kainate/ $\alpha$-amino-3-hydroxy-5-methyl-4-isoxazole propionic acid (AMPA) subtype of GluR as determined by the physiologic and pharmacologic properties in expression systems (Hollmann et al., 1989; Boulter et al., 1990b; Keinanen et al., 1990).

While this report was in preparation, a report of the chromosomal localization of GluR1 appeared (Puckett et al., 1991).

\section{Materials and Methods}

Isolation and characterization of human GluR genes. Cosmid clones were isolated from a human placental DNA library constructed in the vector pWE15 using as host strain DH5 $\alpha$ Escherichia coli; $4.5 \times 10^{5}$ colonies were screened for GluKl-4 by hybridization to radiolabeled probes of rat GluR1-4 cDNA (Hollmann et al., 1989; Boulter et al., 1990 b; Keinanen et al., 1990). Probes were radiolabeled with ${ }^{32} \mathrm{P}$-dCTP to a specific activity of $1-3 \times 10^{9} \mathrm{dpm} / \mu \mathrm{g}$ of DNA by using random hexamers (Amersham) and Klenow fragment of DNA polymerase. Colonies were lifted on Bio-Trans nylon filters, denatured, neutralized, and fixed using the Grunstein procedure (Sambrook et al., 1989) and hybridized for at least $12 \mathrm{hr}$ with the radiolabeled probes in $2 \times$ SSPE, $5 \times$ Denhardt's, and $1 \%$ SDS at $65^{\circ} \mathrm{C}$. Filters were washed in $0.2 \times$ or $0.4 \times$ SSPE $/ 0.1 \%$ SDS at $65^{\circ} \mathrm{C}$ and exposed at $-70^{\circ} \mathrm{C}$ with Kodak X-OMAT film. Following overnight growth in Luria-Bertani broth (Sambrook et al., 1989) containing $50 \mu \mathrm{g} / \mathrm{ml}$ of ampicillin, DNA was isolated from positive clones with a Qiagen kit. 
To tcst whether the cosmid DNA containcd human homologs of the rat GluR genes, partial sequence of subcloned fragments of cosmids containing sequences hybridizing to the homologous rat cDNA probe was obtained. DNA sequence of introns was also obtained from the subclones and used as primers for polymerase chain reactions, thereby avoiding cross-reactivity with the endogenous hamster gene. Subcloning was accomplished as follows. For GluR 1, cosmid DNA was sonicated and blunt ended with Klenow and T4 DNA polymerases, and DNA fragments approximating $250-500$ base pairs (bp) were isolated by agarose gel electrophoresis and eluted using a kit from Gene Clean. These fragments were ligated into an SmaI site of the M13mp9 vector and used to transform competent cells. Recombinants containing coding sequence were identified by hybridization to rat GluR1 cDNA. For GluR2 and GluR3, cosmid DNA was digested with EcoRI and HindIII restriction endonucleases, separated by electrophoresis on agarose gels, transferred to filters, and hybridized to radiolabeled probes for the respective rat cDNAs. Fragments (258 and approximately $900 \mathrm{bp}$ for GluR2 and GluR3, respectively) that hybridized were eluted from agarose gels as above and subcloned into pBluescript $\mathrm{KS}(+)$ vectors digested with EcoRI and HindIII. For GluR4, a $1.8 \mathrm{kbp}$ EcoRI fragment which hybridized with radiolabeled GluR 4 cDNA was subcloned into pBluescript $(+)$. Plasmid DNA was isolated and digested with BamHI restriction endonuclease, and the vector with the remaining $1.2 \mathrm{kbp}$ insert was ligated and used to transform competent cells.

DNA sequencing. DNA of the subcloned fragments was isolated and DNA sequences were determined using dideoxy-sequencing reactions labeled with ${ }^{35}$ S-dATP with the modified T7 DNA polymerase (U.S. Biochem). Primers for sequencing included M13, T3, T7, KS, or SK sequences of the respective vectors. DNA sequence was analyzed with software from Genetics Computer Group (Pearson and Lipman, 1988).

Hybrid cell lines. DNA isolated from a panel of Chinese hamsterhuman hybrid cell lines was used to assign the human GluK genes to human chromosomes (Grissmer et al., 1990; Tabas et al., 1991). DNA from the cell lines was used as template for the polymerase chain reaction (PCR); limitations in amount of DNA available from the cell lines led to selection of the PCR method for these experiments. Oligonucleotide primers were synthesized based on the sequence obtained from the subcloned fragments. Sequences of the PCR primers in $5^{\prime}$ to $3^{\prime}$ direction were as follows: GluR 1 1, TTACGCCGAGCTTTCCCGTTGATA; GluR1 2, GCTGGTG^^TTTTCTCTCCATCC; GluR2 1, GTGCATTCTTTGCCACCTTCATTC; GluR2 2, GGAACCTTCACCAGCCAACATATT; GluR 2 3, CCTACTTGGAGAGTGAGAATGTAC; GluR3 1, TGGAGCCAATCAGGACCCGAT; GluR3 2, GGTTCCTGCTATTTTTCTCTGAGG; GluR4 1, CGTTATGAGGTAAACAGGGAA; GluR4 2, GAAAAGTCAATGACCTCCTCI. DNA was amplified with $0.42 \mu \mathrm{M}$ of each primer in $1 \times$ Taq buffer; $250 \mu \mathrm{M}$ each dATP, dCTP, dGTP, and dTTP; and 0.5-1 U of Thermus aquaticus DNA polymerase (Perkin-Elmer/Cetus). The amplification profile was run for $38 \mathrm{cycles}, 45 \mathrm{sec}$ at $92^{\circ} \mathrm{C}, 60 \sec 60-64^{\circ} \mathrm{C}$, $30 \mathrm{sec}$ at $72^{\circ} \mathrm{C}$

In situ Hybridization. Fluorescent in situ suppression hybridization was carried as previously described (Lichter et al., 1990, 1991; Selleri et al., 1991). Metaphase chromosomes were prepared from lymphocytes isolated by venipuncture from a male or female with normal karyotypes. Biotinylated dCTP and dUTP were incorporated using random primers and the Klenow fragment of DNA polymerase for $15 \mathrm{hr}$ at room temperature. Hybridization reactions were carried out using standard conditions with repetitive sequence blocked by prehybridization with total human placental DNA (Lichter et al., 1990). Chromosomes were counterstained with propidium iodide under conditions that allow a G-banding-like pattern to be observed (J. H. Eubanks, unpublished observations). Images were obtained using a Bio-Rad MRC 600 confocal microscope equipped with a krypton gas laser. Location was determined by observing the position of hybridization relative to the banding patterns generated by computer-enhanced propidium iodide counterstaining.

YAC clone isolation. Yeast artificial chromosome (YAC) clones containing the GluR2 genc werc isolated from a human genomic YAC library constructed in pYAC-4 (Brownstein et al., 1989) made available to us by M. Olson (Washington University, St. Louis, MO). Screening was carried out using PCR on pools of DNA prepared as described (Green and Olson, 1990). The isolated YAC clones were characterized by pulsed field gel analysis for size determination as described (Green and Olson, 1990) on a $1 \%$ low-melt agarose gel for $16-20 \mathrm{hr}$ at $16^{\circ} \mathrm{C}$ using the HEX-CHEF electrode configuration (Chu, 1990). DNA for in situ hybridization was prepared by separation and elution from a lowmelt agarose gel as described (Selleri et al., 1991).

\section{Results}

Identification of human GluR genes. Cosmid clones containing portions of the putative human GluR genes were isolated by hybridization under stringent conditions with the homologous cDNA obtained from rat (Hollmann et al., 1989; Boulter et al., 1990b; Keinanen et al., 1990). Under these conditions, the cosmid clones hybridized to radiolabeled cDNA of mainly one GluR cDNA. This tentative identification of the human gene was tested by subcloning, obtaining partial sequence of an exon (bp specified in Table 1 notes) and comparing the nucleotide and amino acid homology with the rat cDNA (Table 1). In every instance the putative human GluR subcloned exon exhibited high homology with the predicted rat cDNA, with sequence identity ranging from $87 \%$ to $99 \%$. These homologies are based upon the relatively short DNA sequences as specified in the notes to Table 1. Most of the mismatches were conservative since the identity of the amino acid sequences was $100 \%$ for GluR3 and GluR4, 96\% for GluR1, and 98\% for GluR2. The two mismatches for GluR 1 consisted of an aspartate substituted for glutamate at residue 113 and a lysine substituted for a threonine at residue 126 of the rat sequence; these results are identical to those described by Puckett et al. (1991). The single mismatch for GluR2 consisted of alanine substituted for proline at residue 852 of the rat sequence. In every instance, the homology of the human GluR sequence was higher with its respective rat cDNA than with rat cDNAs encoding other GluRs. Together, these data support the conclusion that these cosmid clones contain the likely human homologs of rat GluR1-4.

Chromosomal assignment of human GluR genes. Assignment of GluR genes was made from results of PCR using primers synthesized from DNA sequences identified in the subclones and template DNA isolated from human-Chinese hamster hybrid cell lines (Grissmer et al., 1990; Tabas et al., 1991). Sequence and size estimates from agarose gel electophoresis of subcloned DNA fragments provided predictions of the size of the PCR product. Preliminary experiments optimized conditions for PCR so that a distinct band of the predicted size was obtained for each GluR (approximately 191, 800, 254, and 950 bp for GluR $1-4$, respectively) using human DNA as template; no appropriate size product was obtained using hamster DNA as template (Fig. 1). The assignments of GluR1, GluR3, and GluR4 were chromosomes $5, \mathrm{X}$, and 11 , respectively; no discordant results were obtained with any of these clones (Table 2).

Assignment of GluR2 utilized one primer based upon exon sequence (GluR2 1) and another based upon intron sequence (GluR2 2). The result was most consistent with assignment to chromosome 4 , but a PCR product of the appropriate size was obtained in a single cell line (867) thought not to contain DNA from chromosome 4. Several small fragments were present in karyotypic analyses of cell line 867 , and it seemed possible that some chromosome 4 material may he present. To address this discrepancy, an additional primer (GluR2 3) based upon intron sequence was substituted for primer 2 and identical results were obtained. The results of in situ hybridization were used to compare this assignment with the next most likely possibility, namely, chromosome 22 .

In situ hybridization. In situ hybridization regionally localized 


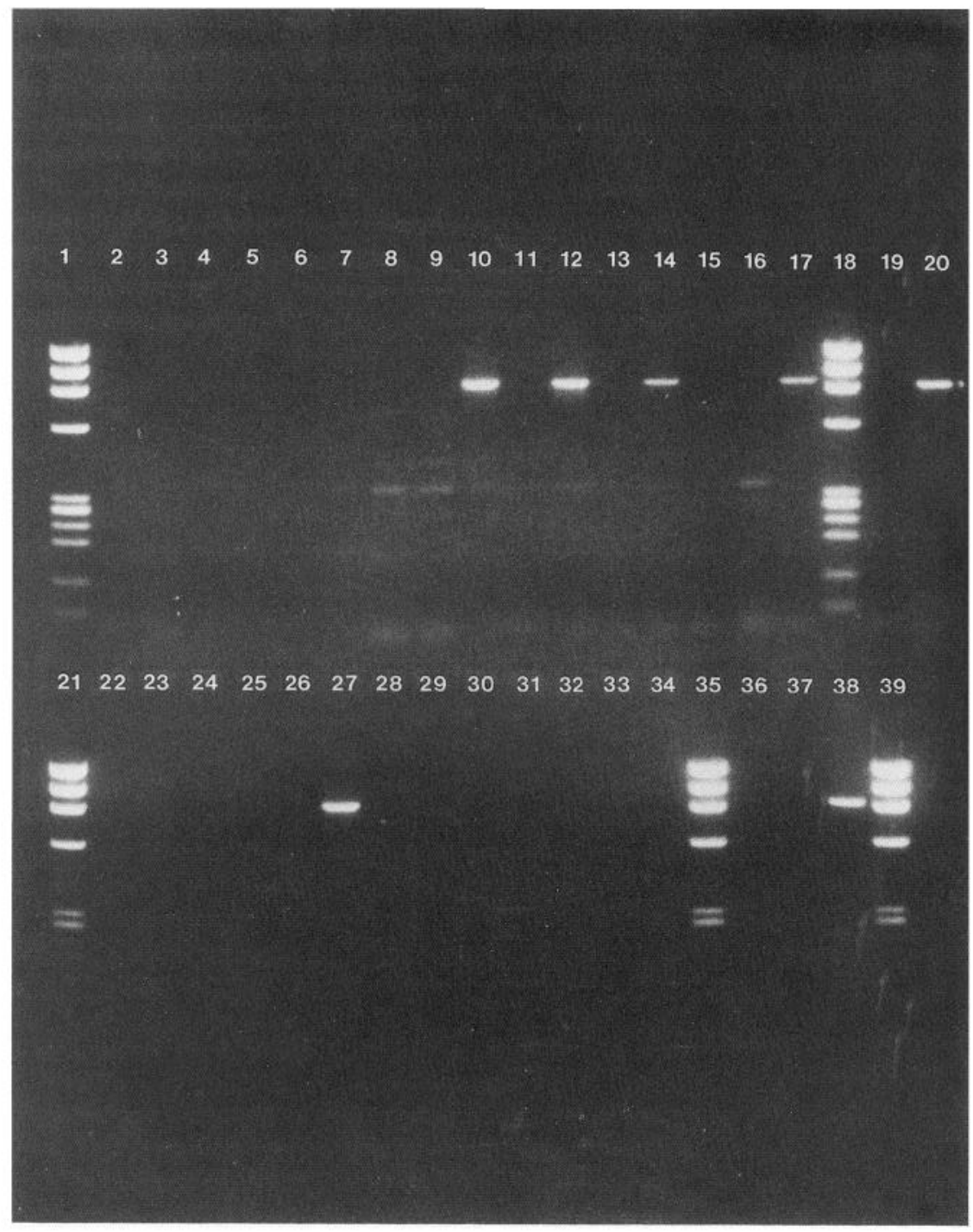

Figure 1. Mapping GluR4 to human chromosomes by PCR of DNA from hamster-human hybrids: photo of ethidium bromide-stained $2 \%$ agarose gel taken under ultraviolet light. Samples were run from two rows of wells (top and bottom). Lanes 1, 18, 21, 35, and 39 contain size markers consisting of $\lambda$-phage DNA digested with HaeIII and $\phi \times 174$. Lanes 10,12, 14, 17, and 27 contain a brightly stained band representing an approximately $900 \mathrm{bp} \mathrm{PCR}$ product obtained using DNA isolated from human-hamster cell hybrids. Lanes 2-9, 11, 13, 15, 16, 22-26, and 28-34 represent PCR results from cell lines negative for the $900 \mathrm{bp}$ product. Reactions in lanes 19 and 37 contained no DNA; 20 and 38, human DNA; and 36, hamster DNA. The faint bands in lanes 19 and 37 likely represent concatamers of primers. The faint bands in lanes 8,9 , and 16 probably represent DNA synthesis from false priming sites.

GluR1 to 5q32-33, GluR2 to $4 q 32-33$, GluR3 to Xq25-26, and GluR4 to Xq22-23 (Figs. 2, 3). In each instance, the hybridization signals were observed in the designated portion of the assigned chromosome in at least 10 cell spreads in addition to the ones presented in Figure 2. The size and banding patterns of each of the chromosomes exhibiting hybridization signals are consistent with the assignment based upon the PCR results.

\section{Discussion}

The results of selective hybridization and partial sequence analysis support the conclusion that the genomic clones isolated represent human homologs corresponding to rat GluR 1-4 (Hollmann et al., 1989; Boulter et al., 1990b) or GluRA-D (Keinanen et al., 1990). Our finding with GluR1 confirms the localization to 5 q33 reported by Puckett et al. (1991). Each of the GluR genes is located on a different chromosome. This contrasts with three other hetero-oligomeric ligand-gated ion-channel mammalian receptors. Genes for two of four isoforms of both the muscle nicotinic $\mathrm{ACh}$ and neuronal $\mathrm{GABA}_{\mathrm{A}}$ receptors mapped to the same interval of a given chromosome, and the remaining two isoforms mapped to different chromosomes (Heidmann et al., 1986; Buckle et al., 1989). Likewise three neuronal nicotinic
ACh receptor genes are tightly linked, forming a cluster within approximately $60 \mathrm{kbp}$ of the rat genome (Boulter et al., 1990a). In situ hybridization to rat brain sections disclosed partly overlapping expression of GluR 1-4 in distinct neuronal populations (Hollmann et al., 1989; Boulter et al., 1990b; Keinanen et al.,

Table 1. Correlation of DNA sequences from subclones of cosmids with DNA sequence of rat GluR1-4 cDNAs

\begin{tabular}{lllll} 
& \multicolumn{2}{l}{ Rat } & & \\
\cline { 2 - 5 } Human & 1 & 2 & 3 & 4 \\
\hline 1 & 87 & 65 & 72 & 64 \\
2 & 74 & 99 & 76 & 85 \\
3 & 84 & 79 & 96 & 82 \\
4 & 82 & 84 & 75 & 93 \\
\hline
\end{tabular}

In this table, the percentage identity of nucleotide sequences of cosmid subclones is compared to rat GluR 1-4 cDNAs. The cosmid clones were tentatively assigned a number (1-4) based upon the rat cDNA exhibiting intense hybridization signals. Note that the nucleotide homology is highest with the respective rat cDNA predicted by hybridization results. The total number of base pairs of exon sequence obtained and the homologous base pairs of the respective rat cDNA are GluR1: 133, 548-681; GluR2: 162, 2415-2577; GluR3: 97, 2609-2706; GluR4: 112, 1509-1621. 
N
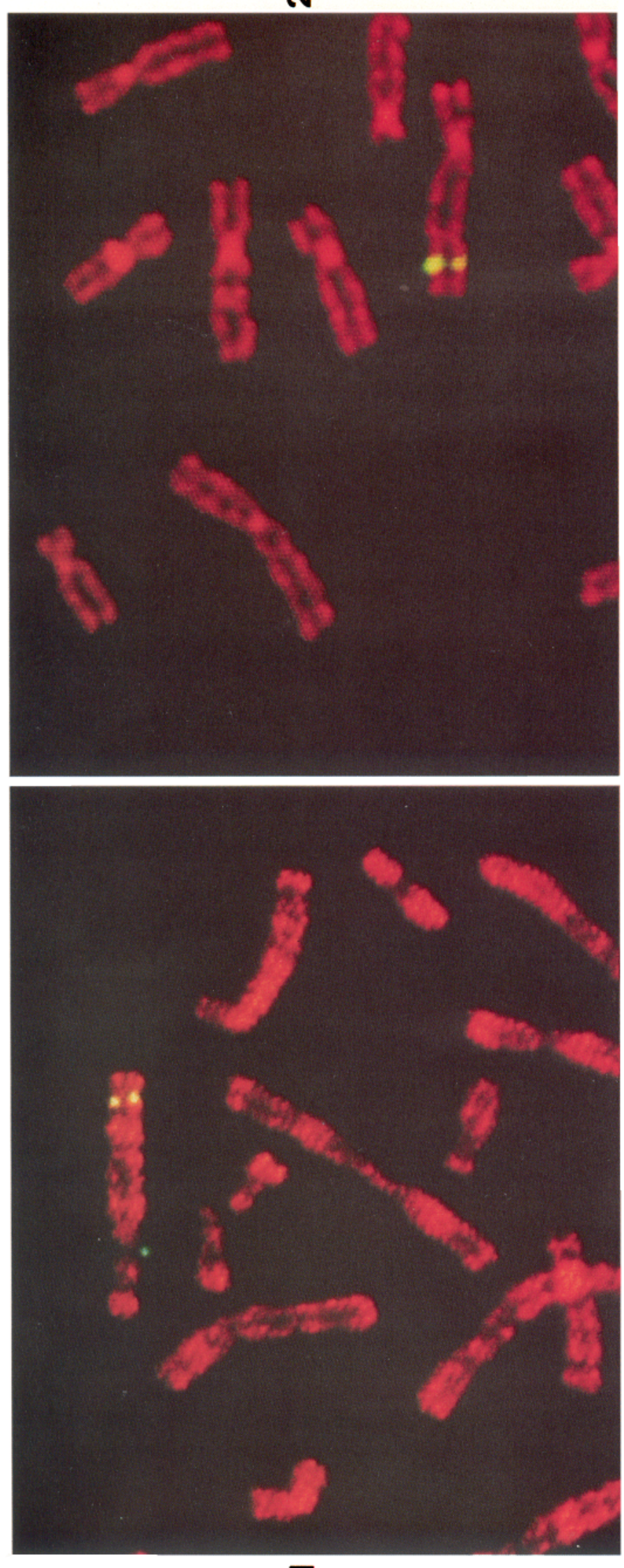

-
$+$
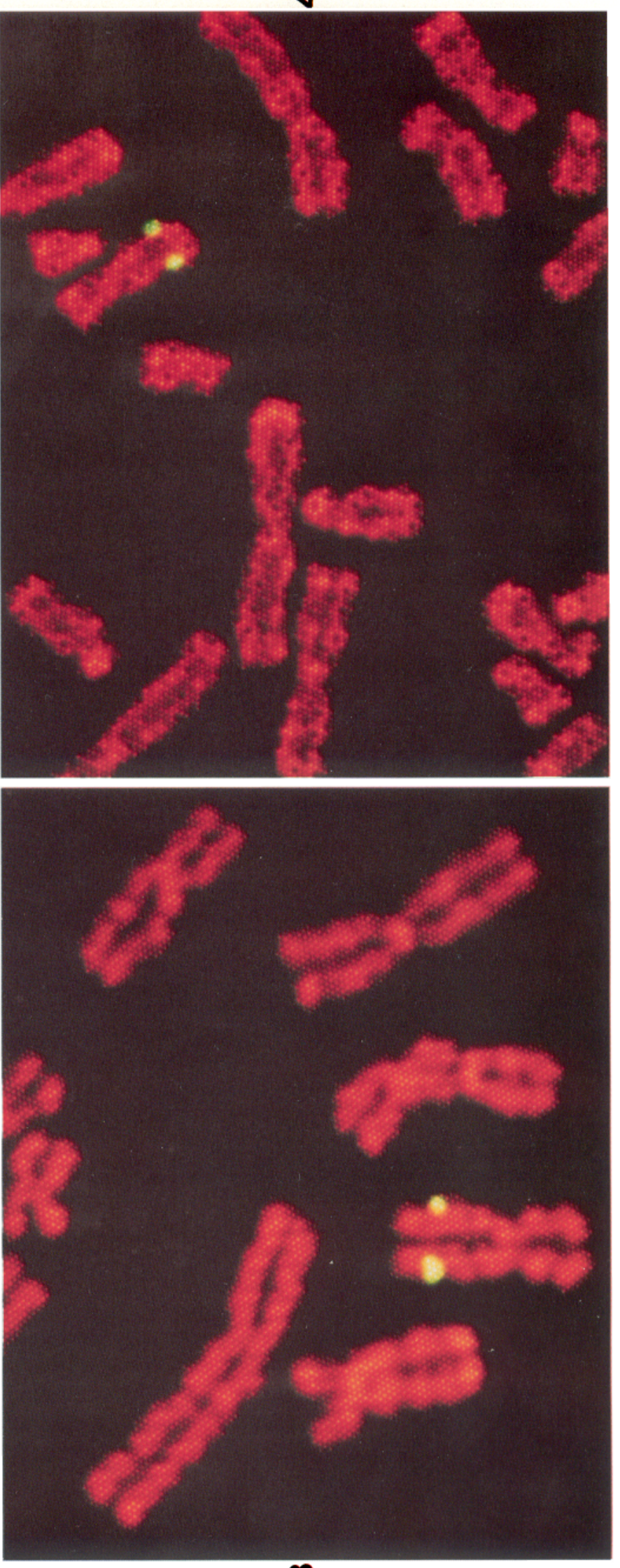
Table 2. Correlation of human sequences detected by PCR using primers based upon DNA sequence of human GluR1-4 DNA and template DNA isolated from Chinese hamster-human somatic hybrids

\begin{tabular}{|c|c|c|c|c|c|c|c|c|c|c|c|c|c|c|c|c|c|c|c|c|c|c|c|c|}
\hline \multirow{2}{*}{$\begin{array}{l}\text { Presence of sequence/ } \\
\text { presence of chromosome }\end{array}$} & \multicolumn{24}{|c|}{ Human chromosomes } \\
\hline & 1 & 2 & 3 & 4 & 5 & 6 & 7 & 8 & 9 & 10 & 11 & 12 & 13 & 14 & 15 & 16 & 17 & 18 & 19 & 20 & 21 & 22 & $\mathrm{X}$ & $\mathrm{Y}$ \\
\hline \multicolumn{25}{|l|}{ GluR1 } \\
\hline \multicolumn{25}{|l|}{ Concordant } \\
\hline$+/+$ & 3 & 2 & 7 & 5 & 24 & 8 & 3 & 6 & 4 & 4 & 6 & 4 & 4 & 7 & 5 & 5 & 2 & 7 & 11 & 4 & 10 & 5 & 4 & 2 \\
\hline$-1-$ & 5 & 5 & 4 & 4 & 5 & 4 & 4 & 4 & 5 & 5 & 5 & 2 & 5 & 5 & 5 & 5 & 5 & 3 & 5 & 5 & 5 & 5 & 5 & 5 \\
\hline \multicolumn{25}{|l|}{ Discordant } \\
\hline$+1-$ & 21 & 22 & 17 & 0 & 0 & 16 & 21 & 18 & 20 & 20 & 18 & 20 & 20 & 17 & 19 & 19 & 22 & 17 & 13 & 20 & 14 & 19 & 20 & 22 \\
\hline$-1+$ & 0 & 0 & 1 & 19 & 0 & 1 & 1 & 1 & 0 & 0 & 0 & 3 & 0 & 0 & 0 & 0 & 0 & 2 & 0 & 0 & 0 & 0 & 0 & 0 \\
\hline Total discordant hybrids & 21 & 22 & 15 & 19 & 0 & 17 & 22 & 19 & 20 & 20 & 18 & 23 & 20 & 17 & 19 & 19 & 22 & 19 & 13 & 20 & 14 & 19 & 20 & 22 \\
\hline Total informative hybrids & 29 & 29 & 29 & 29 & 29 & 29 & 29 & 29 & 29 & 29 & 29 & 29 & 29 & 29 & 29 & 29 & 29 & 29 & 29 & 29 & 29 & 29 & 29 & 29 \\
\hline \% Discordant & 72 & 78 & 62 & 66 & 0 & 59 & 78 & 66 & 69 & 69 & 62 & 79 & 69 & 59 & 66 & 66 & 76 & 66 & 45 & 69 & 48 & 60 & 69 & 78 \\
\hline \multicolumn{25}{|l|}{ GluR2 } \\
\hline \multicolumn{25}{|l|}{ Concordant } \\
\hline$+1+$ & 1 & 0 & 0 & 3 & 4 & 0 & 1 & 1 & 0 & 1 & 1 & 1 & 1 & 2 & 1 & 2 & 0 & 1 & 3 & 0 & 1 & 3 & 0 & 0 \\
\hline$-1-$ & 23 & 23 & 17 & 24 & 5 & 16 & 22 & 19 & 21 & 22 & 20 & 19 & 22 & 18 & 19 & 22 & 22 & 16 & 17 & 22 & 16 & 23 & 21 & 23 \\
\hline \multicolumn{25}{|l|}{ Discordant } \\
\hline$+1-$ & 3 & 4 & 4 & 1 & 0 & 4 & 3 & 3 & 4 & 3 & 3 & 3 & 3 & 2 & 3 & 2 & 4 & 3 & 1 & 4 & 3 & 1 & 4 & 4 \\
\hline$-/+$ & 1 & 1 & 7 & 0 & 19 & 8 & 2 & 5 & 3 & 2 & 4 & 5 & 2 & 6 & 5 & 2 & 2 & 8 & 7 & 2 & 8 & 1 & 3 & 1 \\
\hline Total discordant hybrids & 4 & 5 & 11 & 1 & 19 & 12 & 5 & 8 & 7 & 5 & 7 & 8 & 5 & 8 & 8 & 4 & 6 & 11 & 8 & 6 & 11 & 2 & 7 & 5 \\
\hline Total informative hybrids & 28 & 28 & 28 & 28 & 28 & 28 & 28 & 28 & 28 & 28 & 28 & 28 & 28 & 28 & 28 & 28 & 28 & 28 & 28 & 28 & 28 & 28 & 28 & 28 \\
\hline \% Discordant & 14 & 18 & 39 & 4 & 68 & 43 & 18 & 29 & 25 & 18 & 25 & 29 & 18 & 29 & 29 & 14 & 21 & 39 & 29 & 21 & 39 & 7 & 25 & 18 \\
\hline \multicolumn{25}{|l|}{ GluR3 } \\
\hline \multicolumn{25}{|l|}{ Concordant } \\
\hline$+1+$ & 0 & 0 & 0 & 0 & 3 & 2 & 1 & 1 & 1 & 0 & 1 & 1 & 0 & 1 & 0 & 0 & 0 & 2 & 0 & 0 & 1 & 0 & 3 & 0 \\
\hline$-1-$ & 22 & 24 & 18 & 21 & 5 & 19 & 23 & 20 & 23 & 22 & 22 & 20 & 22 & 19 & 20 & 21 & 23 & 19 & 15 & 22 & 17 & 21 & 25 & 24 \\
\hline \multicolumn{25}{|l|}{ Discordant } \\
\hline$+/-$ & 3 & 3 & 3 & 3 & 0 & 1 & 2 & 2 & 2 & 3 & 2 & 2 & 3 & 2 & 3 & 3 & 3 & 1 & 3 & 3 & 2 & 3 & 0 & 3 \\
\hline$-1+$ & 3 & 1 & 7 & 4 & 20 & 6 & 2 & 5 & 2 & 3 & 3 & 5 & 3 & 6 & 5 & 4 & 2 & 6 & 10 & 3 & 8 & 4 & 0 & 1 \\
\hline Total discordant hybrids & 6 & 4 & 10 & 7 & 20 & 7 & 4 & 7 & 4 & 6 & 5 & 7 & 6 & 8 & 8 & 7 & 5 & 7 & 13 & 6 & 10 & 7 & 0 & 4 \\
\hline Total informative hybrids & 28 & 28 & 28 & 28 & 28 & 28 & 28 & 28 & 28 & 28 & 28 & 28 & 28 & 28 & 28 & 28 & 28 & 28 & 28 & 28 & 28 & 28 & 28 & 28 \\
\hline$\%$ Discordant & 21 & 14 & 36 & 25 & 71 & 25 & 14 & 25 & 14 & 21 & 18 & 25 & 21 & 29 & 29 & 25 & 18 & 25 & 46 & 21 & 36 & 25 & 0 & 14 \\
\hline \multicolumn{25}{|l|}{ GluR4 } \\
\hline \multicolumn{25}{|l|}{ Concordant } \\
\hline$+/+$ & 1 & 0 & 2 & 2 & 5 & 2 & 0 & 2 & 1 & 0 & 5 & 1 & 0 & 1 & 1 & 2 & 0 & 3 & 2 & 1 & 2 & 2 & 1 & 0 \\
\hline$-1-$ & 21 & 22 & 18 & 21 & 5 & 17 & 20 & 19 & 21 & 20 & 23 & 18 & 20 & 17 & 18 & 21 & 21 & 18 & 15 & 20 & 21 & 21 & 21 & 22 \\
\hline \multicolumn{25}{|l|}{ Discordant } \\
\hline$+/-$ & 2 & 5 & 3 & 3 & 0 & 3 & 5 & 3 & 4 & 5 & 0 & 4 & 5 & 4 & 4 & 3 & 5 & 2 & 3 & 4 & 3 & 3 & 4 & 5 \\
\hline$-1+$ & 4 & 1 & 5 & 2 & 18 & 6 & 3 & 4 & 2 & 3 & 0 & 5 & 3 & 6 & 5 & 2 & 2 & 5 & 8 & 3 & 2 & 2 & 2 & 1 \\
\hline Total discordant hybrids & 6 & 6 & 8 & 5 & 18 & 9 & 8 & 7 & 6 & 8 & 0 & 9 & 8 & 10 & 9 & 5 & 7 & 7 & 11 & 7 & 5 & 5 & 6 & 6 \\
\hline Total informative hybrids & 28 & 28 & 28 & 28 & 28 & 28 & 28 & 28 & 28 & 28 & 28 & 28 & 28 & 28 & 28 & 28 & 28 & 28 & 28 & 28 & 28 & 28 & 28 & 28 \\
\hline$\%$ Discordant & 21 & 21 & 29 & 18 & 64 & 32 & 29 & 25 & 21 & 29 & 0 & 32 & 29 & 36 & 32 & 18 & 25 & 25 & 39 & 25 & 18 & 18 & 21 & 21 \\
\hline
\end{tabular}

1990). Moreover, the GluR almost certainly consists of different combinations of these isoforms, the precise combination of which results in markedly different properties of the receptor (Hollmann et al., 1991). Despite the carefully coordinated transcription required for the physiologic expression of these genes, a tandem arrangement of these genes on a given chromosome is not required for this control.
The GluR 1 gene identified here localizes to a region of chromosome 5 , which contains a variety of genes encoding proteins with pivotal roles in signal transduction and which is also syntenic with regions of mouse chromosome to which neurologic disorders have been mapped. Other genes in this area include the $\alpha_{1}$ - and $\beta_{2}$-adrenergic receptors (5q32-34) (Yang-Feng et al., $1990)$ and the $D_{1}$ dopamine receptor (5q31-34) (Sunuhara et

Figure 2. In situ hybridization of cosmid clones containing human GluR $1-4$ genes to metaphase spread of human chromosomes. The two pairs of bright yellow spots are located on equivalent positions of sister chromatids of chromosomes identified as $5,4, X$, and 11 for GluR $1-4$, respectively, based upon PCR and confirmed by G-type banding analysis (Table 2). With respect to GluR2 in particular, no evidence of signal was apparent over chromosome 22 , the alternative chromosome suggested by studies with mapping panels of somatic cell hybrids. The cosmids were labeled with biotinylated nucleotides and detected by incubation with FITC-conjugated avidin; the signal was amplified with biotinylated anti-avidin followed by a subsequent avidin FITC treatment. Chromosomal DNA was counterstained with propidium iodide $(200 \mu \mathrm{g} / \mathrm{ml})$. 


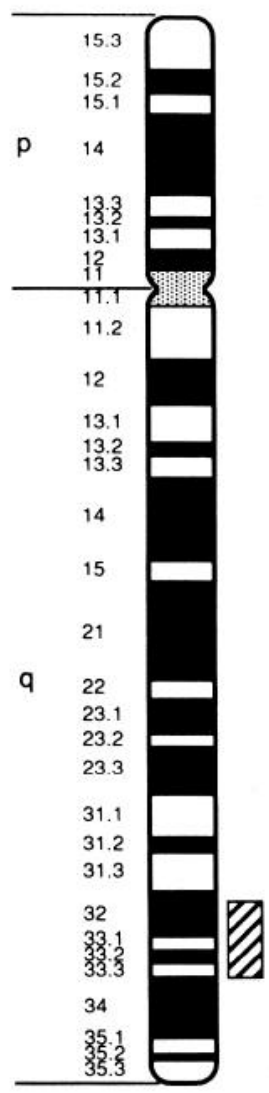

5

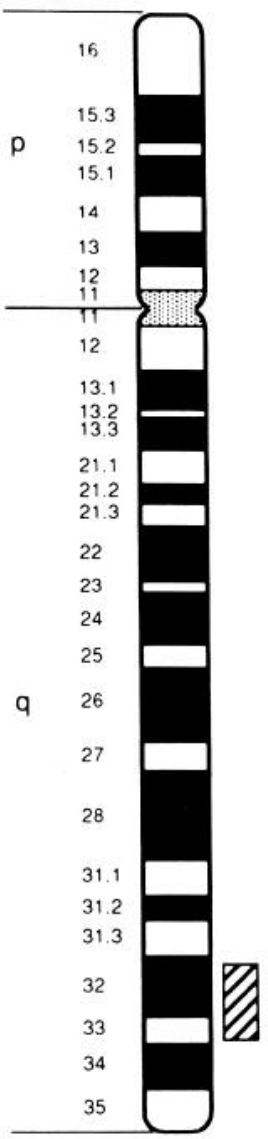

4
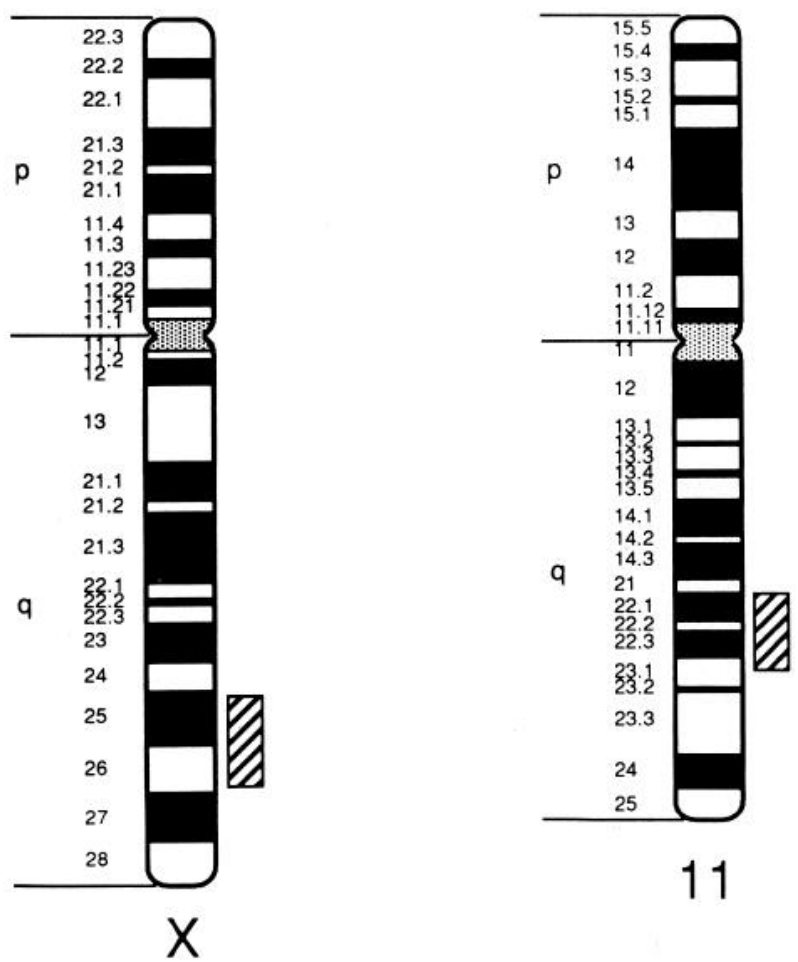

Figure 3. Ideograms of banded chromosomes 5, 4, X, and 11. Hatched areas to the right of each chromosome demarcate region to which GluR 14 , respectively, have been localized. al., 1990). The powerful regulation of GluR function by cAMP and protein kinase A (Greengard et al., 1991; Wang et al., 1991) raises the interesting possibility that the expression of the $\beta_{2}$ adrenergic and $D_{1}$ dopamine receptors in particular might be regulated in coordinate fashion with GluR1. The 5q32-33 region is syntenic with regions of mouse chromosomes 11 and 18; five neurologic disorders have been mapped to the syntenic region of mouse chromosome 11: shaker-2 (sh-2), spasmodic $(s p d)$, vibrator $(v b)$, tipsy $(t i)$, and trembler (Tr) (Lyon and Searle, 1989; Nadeau, 1990). Two neurologic disorders have also been localized to mouse chromosome 18: ataxia $(a x)$ and bouncy $(b c)$ (Lyon and Searle, 1989); the impaired development of the nervous system of $a x$, especially affecting the cerebellum, is of interest in view of the role of GluRs in synapse formation. Determining the location of mouse GluR 1 in relation to these disease loci will facilitate testing the candidacy of this gene. With respect to human diseases mapped to $5 \mathrm{q}$, the location of GluR1 is telomeric to a form of schizophrenia in British and Icelandic families tentatively mapped to 5q11-13 (Sherrington et al., 1988).

The localization of this GluR2 gene to the q32-33 region of chromosome 4 excludes its candidacy for two neurodegenerative diseases mapped by linkage analysis to chromosome 4 . Localization of Huntington's disease, a disorder for which a glutamatergic etiology has been postulated (Choi, 1991), to the p16.3 region of chromosome 4 (Gusella et al., 1983) excludes GluR2 as a candidate gene. Likewise, facioscapulohumeral muscular dystrophy, a familial degenerative disorder postulated to be of neural origin, has been localized to a region telomeric (q35-ter) to GluR2 on chromosome 4 (Wijmenga et al., 1991).

Several genetic diseases have been mapped to the region of the X chromosome to which GluR3 has been localized (q2526). The oculocerebralrenal syndrome of Lowe (OCRL) is manifest by mental retardation, congenital cataract, and proximal renal tubular acidosis (Lowe et al., 1952). Linkage analysis, mapping with somatic cell hybrids, and long-range restriction mapping together have successfully ordered a panel of Xq2426 markers with respect to the OCRL locus (Reilly et al., 1990). Turner et al. (1989) described a family with intellectual handicap, small testes, postpubertal gynecomastia, and skeletal abnormalities and mapped the disorder with linkage analysis to Xq26-27. Shiloh et al. (1990) used linkage analysis to map a syndrome characterized by congenital nerve deafness and albinism to Xq26.3-27.1. The powerful role of glutamatergic synapses in synapse formation (Constantine-Paton et al., 1990) and in excitotoxic death of neurons together with the expression of GluR3 in cerebral cortex and cochlear ganglion raises the possibility that a mutation of GluR 3 could contribute to these disorders.

The GluR 4 gene has been localized to a region of chromosome 11 (q22-23) to which a number of neural genes and possibly an epileptic mouse mutant have been mapped. Genes encoding the $\mathrm{D}_{2}$ subtype of dopamine receptor and N-CAM, a cell surface glycoprotein with morphoregulatory properties in neural development (Cunningham et al., 1987), have been localized to 11q23 (McConville et al., 1990). The $E /$ mouse exhibits complex partial seizures with behavioral, electroencephalographic, and pharmacologic features similar to those in humans. The principal gene responsible for this phenotype, $E l-1$, has been mapped to a region of approximately 20 centimorgans on mouse chromosome 9 by analyses of backcrosses of mutants with seizure resistant strains using proviral markers (Lyon and Searle, 1989). Among the human chromosome segments syntenic with this 
region of mouse chromosome 9 is part of $11 \mathrm{q}$, as evident by the marker glutathione $S$-transferase (Lyon and Searle, 1989; Nadeau, 1990). The anticonvulsant properties of the kainate/ AMPA receptor antagonist CNQX (McBain et al., 1988), together with the increased ${ }^{3} \mathrm{H}$-AMPA binding in the dentate granule cells of hippocampi surgically excised from humans with severe complex partial seizures (Hosford et al., 1991), warrant investigation of the precise location of GluR 4 in relation to $E l-1$.

Among the human nervous system disorders mapped to this region of chromosome 11 , ataxia telangiectasia is an autosomal recessive disease of childhood characterized by progressive cerebellar degeneration and both immunologic and endocrine deficiencies; the defective gene has been mapped by linkage analysis to 1 lq22-23 (Gatti et al., 1988). Smith et al. (1989) have described the association of a 9-11 chromosomal translocation with bipolar disorder in a single pedigree; the translocation breakpoint on chromosome 11 was pinpointed to $11 \mathrm{q} 22.3-\mathrm{q} 23.1$ with cytogenetic and in situ hybridization analyses. This disorder is characterized by episodic mania (e.g., elevated mood, racing thought, impaired function) and episodic depression. St. Clair et al. (1990) described the association of a translocation of 11q21-q22 with schizophrenia, schizoaffective disorder, and major depression in multiple pedigrees. A fourth nervous system disorder, tuberous sclerosis, has been mapped in some families to 9 q34 and in others to $11 \mathrm{q} 22-q 23$ (Janssen et al., 1990). This is a dominantly inherited neurocutaneous disorder characterized by seizures, varying degrees of mental impairment, and hamartomas of multiple organs including skin, kidney, and brain. Identification of a polymorphism in the GluR4 gene would permit examining its proximity to these disorders.

Note added in proof: After acceptance of this manuscript, Sun et al. (1992) reported cloning of a human brain cDNA fragment which contained part of the coding region of a gene homologous to rat GluR2. The sequence of this fragment was not reported, thereby precluding its comparison with the putative human homolog of GluR2 reported here. Hybridization to blots of DNA isolated from human-hamster somatic cell hybrids localized this fragment to $4 \mathrm{q} 25-34.3$, a region compatible with the localization of GluR2 to 4q32-33 described in the present report. The cloning of a full length human brain cDNA homologous to GluR 1 was also reported and the amino acid sequence of the portion corresponding to the exon of GluR 1 identified here is identical. Sun et al. (1992) localized the cDNA to human chromosome $5 \mathrm{q} 31.3-33.3$ by Southern analysis of somatic cell hybrids, a localization consistent with the present findings.

\section{References}

Bettler B, Boulter J, Hermans-Borgmeyer I, O’Shea-Greenfield A, Deneris ES, Moll C, Borgmeyer U, Hollmann M, Heinemann S (1991) Cloning of a novel glutamate receptor subunit, GluR5: expression in the nervous system during development. Neuron 5:583-595.

Boulter J, O'Shea-Greenfield A, Duvoisin RM, Connolly JG, Wada E, Jensen A, Gardner PD, Ballivet M, Deneris ES, McKinnin D, Heinemann S, Patrick J (1990a) $\alpha 3, \alpha 5$, and $\beta 4$ : three members of the rat neuronal nicotinic acetylcholine receptor-related gene family form a gene cluster. J Biol Chem 265:4472-4482.

Boulter J, Hollmann M, O'Shea-Greenfield A, Hartley M, Deneris F, Maron C, Heinemann S (1990b) Molecular cloning and functional expression of glutamate receptor subunit genes. Science 249:10331037.

Brownstein BH, Silverman GA, Little RA, Burke DT, Korsmeyer SJ, Schlessinger D, Olson MV (1989) Isolation of single-copy human genes from a library of yeast artificial chromosome clones. Science 244:1348-1351.

Buckle VJ, Fujita N, Ryder-Cook AS, Derry JMJ, Barnard PJ, Lebo RV, Schofield PR, Seeburg PH, Bateson AN, Darlison MG, Barnard EA (1989) Chromosomal localization of GABA A receptor subunit genes: relationship to human genetic disease. Neuron 3:647-654.

Choi DW (1991) Glutamate neurotoxicity and diseases of the nervous system. Neuron 1:623-634.

Chu G (1990) Pulsed-field gel electrophoresis: theory and practice. Methods [companion to Methods Enzymol] 1:129-142.

Constantine-Paton M, Cline HT, Debski E (1990) Patterned activity, synaptic convergence, and the NMDA receptor in developing visual pathways. Annu Rev Neurosci 13:129-134.

Cunningham BA, Hemperly JJ, Murray BA, Prediger EA, Brackenbury R, Edclman GM (1987) Neural cell adhesion molecule: structure, immunoglobulin-like domains, cell surface modulation, and alternative RNA splicing. Science 236:799-806.

Dingledine R, McBain CJ, McNamara JO (1990) Excitatory amino acid receptors in epilepsy. Trends Pharmacol Sci 11:334-338.

Egebjerg J, Bettler B, Hermans-Borgmeyer I, Heinemann S (1991) Cloning of a cDNA for a glutamate receptor subunit activated by kainate but not AMPA. Nature 351:745-748

Gatti RA, Berkel I, Boder E, Braedt G, Charmley P, Concannon P, Ersoy F, Foroud T, Jaspers NGJ, Lange K, Lethrop GM, Leppert M, Nakamura Y, O'Connell P, Paterson M, Salser W, Sanal O, Silver J, Sparkes RS, Susi E, Weeks DE, Wei W, White R, Yoder F (1988) Localization of an ataxia-telangiectasia gene to chromosome 1 lq2223. Nature 336:577-580.

Green ED, Olson MV (1990) Systcmatic screening of yeast artificial chromosome libraries by use of the polymerase chain reaction. Proc Natl Acad Sci USA 87:1213-1217.

Greengard P, Jen J, Nairn AC, Stevens CF (1991) Enhancement of the glutamate response by cAMP-dependent protein kinase in hippocampal neurons. Science 253:1135-1138.

Grissmer S, Dethlefs B, Wasmuth JJ, Goldin AI, Gutman GA, Cahalan MD, Chandy KG (1990) Expression and chromosomal localization of a lymphocyte $\mathrm{K}^{+}$channel gene. Proc Natl Acad Sci USA 88:94119415 .

Gusella JF, Wexler NS, Conneally PM, Naylor SL, Anderson MA, Tanzi RE, Watkins PC, Ottina K, Wallace MR, Sakaguchi AY, Young A, Shoulson I, Bonilla E, Martin JB (1983) A polymorphic DNA marker genetically linked to Huntington's disease. Nature 306:234-238.

Headley PM, Grillner S (1990) Excitatory amino acids and synaptic transmission: the evidence for a physiological function. Trends Pharmacol Sci 11:205-211.

Heidmann O, Buonanno A, Geoffroy B, Robert B, Guenet JL, Merlie JP, Changeux JP (1986) Chromosomal localization of muscle nicotinic acetylcholine receptor genes in the mouse. Science 234:866868

Hollmann M, O'Shea-Greenfield A, Rogers SW, Heinemann S (1989) Cloning by functional expression of a member of the glutamate receptor family. Nature 342:643-648.

Hollmann M, Hartley M, Heinemann S (1991) Calcium permeability of KA-AMPA-gated glutamate receptor channels depends on subunit composition. Science 252:851-853.

Hosford DA, Crain BJ, Cao Z, Bonhaus DW, Friedman AH, Okazaki MM, Nadler JV, McNamara JO (1991) Increased AMPA-sensitive quisqualate receptor binding and reduced NMDA receptor binding in epileptic human hippocampus. J Neurosci 11:428-434.

Janssen LAJ, Sandkuyl LA, Merkens EC, Maat-Kievit JA, Sampson JR, Fleury P, Hennekam RCM, Grosveld GC, Lindhout D, Halley DJJ (1990) Genetic heterogeneity in tuberous sclerosis. Genomics 8:237-242.

Keinanen K, Wisden W, Sommer B, Werner P, Herb A, Verdoorn TA, Sakmann B, Seeburg PH (1990) A family of AMPA-selective glutamate receptors. Science 249:556-560.

Lichter P, Chang Tang C, Call K, Hermanson G, Evans GA, Housman D, Ward DC (1990) High-resolution mapping of human chromosome 11 by in situ hybridization with cosmid clones. Science 247 : 64-69.

Lichter P, Boyle AL, Cremer T, Ward DC (1991) Analysis of genes and chromosomes by nonisotopic in situ hybridization. Genet Anal Tech Appl 8:24-35.

Lowe CU, Terrey M, MacLachlan EA (1952) Organic-aciduria, de- 
creased renal ammonia production, hydrophthalmos, and mental retardation. Am J Dis Child 83:164-184.

Lucas DR, Newhouse JP (1957) The toxic effect of sodium L-glutamate on the inner layers of the retina. Arch Ophthalmol (Copenh) 58:193-201.

Lyon JF, Searle AG (1989) Genetic variants and strains of the laboratory mouse. New York: Oxford UP.

McBain CJ, Boden P, Hill RG (1988) The kainate/quisqualate receptor antagonist, CNQX, blocks the fast component of spontaneous epileptiform activity in organotypic cultures of rat hippocampus. Neurosci Lett 93:341-345.

McConville CM, Formstone CJ, Hernandez D, Thick J, Taylor AMR (1990) Fine mapping of the chromosome 11q22-23 region using PFGE, linkage and haplotype analysis; localization of the gene for ataxia telangiectasia to a $5 \mathrm{cM}$ region flanked by NCAM/DRD2 and STMY/CJ52.75, phi2.22. Nucleic Acids Res 18:4335-4343.

Morris RGM (1989) Synaptic plasticity and learning: selective impairment of learning in rats and blockade of long-term potentiation in vivo by the $N$-methyl-D-aspartate receptor antagonist AP5. J Neurosci 9:3040-3057.

Nadeau JH (1990) Linkage and synteny homologies between mouse and man. Bar Harbor, ME: Jackson Laboratory.

Olney JW (1986) Inciting excitotoxic cytocide among central neurons. Adv Exp Med Biol 203:631-645.

Pearson WR, Lipman DJ (1988) Improved tools for biological sequence comparison. Proc Natl Acad Sci USA 85:2444-2448.

Puckett C, Gomez CM, Korenberg JR, Tung H, Meier TJ, Ning Chen X, Hood L (1991) Molecular cloning and chromosomal localization of one of the human glutamate receptor genes. Proc Natl Acad Sci USA 88:7557-7561.

Reilly DS, Lewis RA, Nussbaum RL (1990) Genetic and physical mapping of Xq24-q26 markers flanking the Lowe oculocerebrorenal syndrome. Genomics 8:62-70.

Sambrook J, Fritsch EF, Maniatis T (1989) Molecular cloning: a laboratory manual. Cold Spring Harbor, NY: Cold Spring Harbor Laboratory.

Selleri L, Hermanson GG, Eubanks JH, Lewis KA, and Evans GA (1990) Molecular localization of the 1 1q24, 22q12 translocation of Ewing's sarcoma by chromosomal in situ suppression hybridization. Proc Natl Acad Sci USA 88:887-891.

Selleri L, Hermanson GG, Eubanks JH, Evans GA (1991) Chromosomal in situ hybridization using yeast artificial chromosomes. Genet Anal Tech Appl 8:59-66.

Sherrington R, Brynjolfsson J, Petursson H, Potter M, Dudleston K, Barraclogh B, Wasmuth J, Dobbs M, Gurling H (1988) Localization of a susceptibility locus for schizophrenia on chromosome 5. Nature 336:164-167.

Shiloh Y, Litvak G, Ziv Y, Lehner T, Sandkuyl L, Hildesheimer M, Buchris V, Cremers FPM, Szabo P, White BN, Holden JJA, Ott J (1990) Genetic mapping of X-linked albinism-deafness syndrome (ADFN) to Xq26.3-q27.1. Am J Hum Genet 47:20-27.
Simon RP, Swan JH, Griffiths T, Meldrum BS (1984) Blockade of $\mathrm{N}$-methyl-D-aspartate receptors may protect against ischemic damage in the brain. Science 226:850-852.

Smith M, Wasmuth J, McPherson JD, Wagner C, Grandy D, Civelli O, Potkin S, Litt M (1989) Cosegregation of an 11q22.3-9p22 translocation with affective disorder: proximity of the dopamine D2 receptor gene relative to the translocation breakpoint. Am J Hum Genet [Suppl] 45:A220.

Spencer PS, Nunn PB, Hugon J, Ludolph AC, Ross SM, Roy DN, Robertson RC (1987) Guam amyotrophic lateral sclerosis-Parkinsonism-dementia linked to a plant excitant neurotoxin. Science 237 517-522.

St. Clair D, Blackwood D, Muir W, Carothers A, Walker M, Spowart G, Gosden C, Evans HJ (1990) Association within a family of a balanced autosomal translocation with major mental illness. Lancet 336:13-16.

Sun W, Ferrer-Montiel AV, Schinder AF, McPherson JP, Evans GA, Montal M (1992) Molccular cloning, chromosomal mapping, and functional expression of human brain glutamate receptors. Proc Natl Acad Sci USA 89:1443-1447.

Sunuhara RK, Niznik HB, Weiner DM, Stormann TM, Brann MR, Kennedy JL, Gelernter JE, Rozmahel R, Yang Y, Israel Y, Seeman P, O'Dowd BF (1990) Human dopamine D1 receptor encoded by an intronless gene on chromosome 5. Nature 347:80-83.

Tabas JA, Zasloff M, Wasmuth JJ, Emanuel BS, Altherr MR, McPherson JD, Wozney JM, Kaplan FS (1991) Bone morphogenetic protein: chromosomal localization of human genes for BMP1, BMP2A, and BMP3. Genomics 9:283-289.

Turner L, Gedeon A, Mulley J, Sutherland G, Rae J, Power K, Arthur I (1989) Borjeson-Forssman-Lehmann syndrome: clinical manifestations and gene localization to Xq26-27. Am J Med Genet 34:463469.

Van Den Pol AN, Wuarin JP, Dudek FE (1990) Glutamate, the dominant excitatory transmitter in neuroendocrine regulation. Science 250:1276-1278.

Wang L-Y, Salter MW, MacDonald JF (1991) Regulation of kainate receptors by cAMP-dependent protein kinase and phosphatases. Science 253:1132-1135.

Werner P, Voigt M, Keinanen K, Wisden W, Seeburg PH (1991) Cloning of a putative high-affinity kainate receptor expressed predominantly in hippocmpal CA3 cells. Nature 351:742-744.

Wieloch $T$ (1985) Hypoglycemia-induced neuronal damage prevented by an $N$-methyl-D-aspartate antagonist. Science 230:681-683.

Wijmenga C, Padberg GW, Moerer P, Wiegant J, Liem L, Brouwer OF, Milner EC, Weber JL, van Ommen GB, Sandkuyl LA (1991) Mapping of facioscapulohumeral muscular dystrophy gene to chromosome 4q35-qter by multipoint linkage analysis and in situ hybridization. Genomics 9:570-575.

Yang-Feng TL, Xue F, Zhong W, Cotecchia S, Frielle T, Caron MG, Lefkowitz RJ, Francke U (1990) Chromosomal organization of adrenergic receptor genes. Proc Natl Acad Sci USA 87:1516-1520. 